VALUES, RITUAL AND THE MANAGEMENT OF INTERCULTURAL DIVERSITY: TESTING THE GROUND IN THE MEDIA

\author{
Johanna Sumiala $^{1}$
}

From anthropology of religion to anthropology of media

Professor Joel Robbins' article Religious Pluralism and Value Pluralism: Ritual and the Management of Intercultural Diversity offers an important insight into the study of value pluralism and ritual, taking an approach relevant not only for the study of religion and anthropology, but also sociology and social theory at large.

In his article, Robbins approaches ritual as an aspect of religion particularly involved in the expression of values, which he defines as "those ends that are culturally defined as worth orienting action toward". In the condition of value pluralism, every social formation contains a multiplicity of values; hence, the aim to better understanding those relationships that hold between values. According to Robbins, two theoretical assumptions can be made in this condition: the monist position and the pluralist position. Put simply, in the monist position, values are either perceived to work in a hierarchy or to gain their own worth by contributing to the realisation of the value highest in the hierarchy; the supervalue, if you will. Meanwhile, value pluralists argue for a conflict between different values. In this condition, pursuing one value may result in failing to pursue the other, and therefore (tragic) choices have to be made.

In Robbins' interpretation, both of these views may be at work in peoples' lives linearly and/or simultaneously. In certain cases and moments, we work by monist solutions; in other cases, we experience an implicit or explicit conflict of values and a need to make choices between values. Simultaneous tendencies of pushing and pulling between monist and pluralist tendencies are found in peoples' lives.

Furthermore, Robbins states that in a condition in which there are multiple values at play, "rituals are one of the places where people are able to encounter single values clearly expressed and to act on them one at a time". He goes further to identify two branches of ritual studies: representational and performative. While in a representational framework rituals are seen to accomplish a kind of highlighting and perfecting of social representations that help people 
experience and realise a single value fully, in a performative framework rituals are seen to help people commit to the values performed in the ritual through the act of participating in (performing) those rituals. While it may be useful to make this analytical distinction for the purpose of developing ritual theory, the representational and performative elements are intertwined in many ways in ritual practice.

In this commentary, I wish to discuss Robbins' key idea of rituals expressing one single value at a time by reflecting his argument in another context. This attempt to discuss value and ritual and the management of intercultural diversity requires a radical contextual shift; a move from the anthropology of religion and Papua New Guinea to the anthropology of media and presentday Britain. By making this courageous move, I wish to illuminate how these ideas and theories of ritual and value travel from one cultural and social setting to another. This, I understand, is also the intention of Robbins himself, as he states: “One task for anthropology, I suggested, is to study how these tensions between monism and pluralism work out in concrete social formations and in the lives of the people who live within them."

However, certain clarifications must be made first, involving what we understand the media to be, how we understand it and its relationship with values.

Birgit Meyer $(2013,4)$ argues for the relevance of studying media in anthropology by explaining the mediated character of all communication:

What people share, the 'social', their 'culture', is produced through practices of transmission in which media are made to bridge, but by the same token affirm, the distance and difference between those involved in communication. ...As communication cannot occur by immediate intuition (as a romanticist view would suggest), but necessarily depends on external media... - we need to analyse communication as a concrete and material process.

She goes on to make an explicit statement regarding media as a social form significant for the performance of values.

Therefore, if we want to understand social processes of sharing imaginaries, meanings and values, of binding, bonding and collaboration, we need to turn to media. They are in the middle, bridging the unavoidable differences that exist not only between 'senders' and 'receivers' but also between a mass of anonymous audiences, drawing them into an 'imagined community' (Anderson, 1991) or, as I would put it, an 'aesthetic formation' (Meyer, 2009, pp. 6- 
11), characterized by common ideas, values and practices that emerge and are sustained through sharing media. (Meyer 2013, 5, emphasis by JS)

When discussing media as a social form in a contemporary society such as Britain, we encounter vagueness (cf. Couldry 2012, 62). For one, the term media itself is ambiguous. It may refer to institutions and infrastructures that produce and distribute particular types of content, but media also is that content (Couldry 2012, 2). Consequently, we may identify values related to media as an institution, infrastructure and/or content. In this line of thinking, different aspects of media address and activate social forms of different kinds. We may analyse media as a social form constructed around the nation-state and nation building, and place special emphasis on the media institutions and their role as content-constructing imagined communities, to use the lexicon of the previously mentioned Benedict Anderson (1991) and many others. However, media may also be perceived as a social form on a global scale. The late Roger Silverstone (2007) discussed contemporary media creating and maintaining a global civil sphere, a shared public imaginary with competing perspectives. Worldwide actors such as $C N N, B B C$ World News and Al Jazeera play a major role in shaping the global public agenda. At the micro-level we find local community media, organised around e.g. radio or other local media, fostering local imaginations (cf. Ginsburg, AbuLughod \& Larkin 2002). In today's world we also need to recognise diasporic media, in which sociality is created and maintained around numerous virtual communities, often taking place in and via the different forms and applications of social media (interestingly enough, many of these sites and services are owned by global media businesses such as Google). Overall, the processes of digitalisation and convergence tend to blur the lines between different media and the related social form, thus creating new types of hybrid social forms (see e.g. Murphy \& Kraidy 2003; Sumiala 2012; Sumiala \& Tikka 2011). This variety of media as a social form also carries certain instability and uncertainty in its communication of values. In many cases, individual values when played out can be in conflict with each other. To give a simple example, we may listen to local indigenous media and join in its call for the freedom of an individual voice, and thereafter turn to global media to share a mediatized reality with a heavy emphasis on the centralisation of communication power. Obviously, there might also be value conflicts inside of different media (cf. Castells 2009).

From the monist point of view, we may claim that in the hierarchy of values attention is among the most appreciated in today's media. All the other values, such as profit, pleasure, participation and belonging, are subordinate to this supervalue. Without attention, and the related 
visibility and recognition, media as a social form ceases to exist. Consequently, one of the driving forces for the contemporary media is an ongoing battle for the interest and awareness of the public (cf. Couldry 2012).

As we consider in more detail the dynamics between media as a social form and value pluralism, we need to recognise that neither media nor values are created or sustained in a vacuum, and that they are not abstract constellations. The analysis of media and values must be embedded in practices, which brings us back to Robbins and his argument relating to the role of ritual.

Ritual scholar Ronald Grimes provides an interesting manner of considering the dynamics between media and ritual, which is useful in this context. Grimes (2006, 3-4) offers the following important insight into the evolving relationship between media and ritual, echoing the Durkheimian classical distinction between the two realms of social reality, i.e. the sacred and profane:

Not long ago, the terms 'ritual' and 'media' would have been regarded as labels for separate cultural domains - the one sacred, the other secular; the one term designating a religious activity and the other denoting tools and processes for transferring information. Media not only intruded upon but also profaned rituals. ... But things have changed. Now, media often validate rites. The presence of cameras announces, 'This is an important event.' Today, both notions, ritual and media, are understood quite differently, and the connections between them are remarked upon with growing frequency in scholarly writing. ... The media, some claim, are ritual in contemporary form. However, when a metaphor (media as ritual) collapses into a simple identity (media are ritual), both terms become useless. Either strategy - segregating or equating - oversimplifies the complex ways in which media, ritual and modern society interact.

In Grimes' interpretation, the two categories (ritual and media as sacred and profane) are today seen as overlapping instead of mutually exclusive. Second, he notes certain pitfalls in this understanding that can blur the distinction between the two domains and cause both terms to lose their analytical potential; hence, it is important to develop a more nuanced understanding of ritual. Doing so first requires identifying the kind of ritual involved in any given case: is it a ritual in the sense of pilgrimage, celebration, sacrifice or rite of passage? Furthermore, it is necessary to establish in what respect media are ritual and in what respect they are not. Grimes $(2006,12)$ contends that a fruitful discussion on media and ritual is possible only when the two domains are "neither equated nor segregated but rather differentiated and conceived as sharing a common boundary". 


\section{VALUES, RITUAL AND THE MANAGEMENT OF INTERCULTURAL DIVERSITY: TESTING THE GROUND IN THE MEDIA}

Mediatized rituals of death and value pluralism

I will now examine how this interplay between media, rituals and values was evident in one particular ritual event substantially played out in and via the media, the death of the former British Prime Minister, Baroness Margaret Thatcher. ${ }^{1}$

Lady Thatcher died of a stroke on 8 April 2013 at the age of 87, after having suffered poor health for several years. News of her death broke in Britain locally and nationally, and globally in the mainstream and social media, and immediately prompted mixed reactions among the British public and elsewhere in the world. Her death brought about a rich variation of ritual practices that emerged in and via the diverse media on different scales. The ritualization began after Thatcher's spokesman confirmed her death to the Press Association, which issued the first wire report to newsrooms. As a national symbol of mourning, the Union Flag was flown at half-mast at many sites associated with the late Prime Minister and the nation's symbolic power centres, such as Downing Street, Buckingham Palace and Parliament. A site of pilgrimage emerged when people began to bring flower and candles to leave outside Thatcher's home.

Perhaps the most characteristic element of this intensive ritualization was the level of controversy surrounding her personality and political heritage. Her supporters paid tribute to Thatcher as Britain's greatest peacetime Prime Minister by posting comments in social media, uploading mourning videos to YouTube and writing obituaries. She may have been praised as an 'Iron Lady' of the era, but many celebrated her death. It seemed her opponents in England and elsewhere in the world had waited for Thatcher to die to be allowed to express their anger and hatred against her in public. Many openly declared in and via the media their extreme dislike of her, while spontaneous street parties were organized, with one such event held in Brixton, London. In one YouTube video, people were seen dancing, drinking and carrying posters with slogans relating to her death, and Facebook and Twitter messages circulated to celebrate her death. All of these ritual performances were carried out in a deeply mediatized manner. While some mourning rituals

1

In the empirical analysis I draw on my ongoing media ethnographic work on the death of Margaret Thatcher. In my fieldwork I combine different forms of ethnography, ranging from urban ethnography, ethnography of representations and virtual ethnography. In addition to participation observation and collecting media materials, I have also conducted interviews relating to people's reactions to Thatcher's death in London and elsewhere in Britain. 
were orchestrated by the mainstream media, with the BBC and national newspapers playing a key role as national institutions, others were organized by ordinary social media users. In many cases, the line between the two became blurred as ritual practices crossed over from one media-related context to another. The Wizard of $\mathrm{Oz}$ song, 'Ding, Dong! The Witch is Dead', is an example par excellence, as it was attributed symbolic value by Thatcher's opponents in the ritualized battle against her. The song became massively popular in the week after Thatcher's death, and reached No. 2 in the British national music chart after selling over 52,000 copies. It was due to be played on the BBC Radio 1 chart rundown, but instead the BBC played a tape in which it explained why it chose not to play the song.

Thatcher's funeral took place on 17 April, and in line with her wishes she received a ceremonial procession including full military honours. A church service was held at St Paul's Cathedral, attended by Queen Elizabeth and Prince Philip. This was only the second time (the first was Winston Churchill in 1965) in the Queen's reign that she had attended the funeral of a former Prime Minister. Later, Thatcher's ashes were interred in the grounds of the Royal Hospital Chelsea, next to those of her husband Denis. The service and interment were unpublicised private events, but the funeral ceremony was transformed into a media event, broadcast widely on television, and print newspapers followed the events online and updated material as the ceremony proceeded. One informant who had participated in the ceremony as part of the crowd described the atmosphere as "jolly". Many came to pay their respects and share in the historic moment, while others criticized the public money spent on her funeral as, after all, in life she was in favour of privatization.

Returning to Robbins' argument on value pluralism and rituals, it is no exaggeration to say that in this mediatized ritualization of Lady Thatcher's death, the plurality of values was evident. From a monist perspective, the media events surrounding her death and funeral constituted a hierarchy of values embedded in the present-day logic of a media event. At the pinnacle of this hierarchy was the attention paid to her death. As one British journalist informant pointed out, the media was well prepared for Thatcher's death given her age and poor health, meaning it had ample time to prepare; the obituaries were pre-written and her funeral broadcast rehearsed by many professional media organizations. After her death, and during the funeral, the official tone of reporting in the mass media followed the mode and style typical following the death of a public figure. The media repeated a narrative of her life and political career from humble origins to the first female British Prime Minister. One element of the reporting focused on the public reaction to 
her death, and the mass media provided not only national but also global coverage of the contradictory and highly ritualized practices performed in the aftermath of Thatcher's death, consequently transferring the media to the social centre of the historic event (see e.g. Couldry 2003).

However, if we consider the mourning and celebration rituals played out by the people in and via the media, deeply conflicting values become apparent. In some mourning rituals, people gathered to pay their respects to Thatcher's personal and political achievements. Her supporters admired her, and her political ideas were praised and confirmed in those rituals. In other rituals, a sense of togetherness was constructed around celebrating Thatcher's death and mocking her political career, involving rituals in which people expressed their anger and frustration and claimed she had destroyed the country. In these rituals, Thatcher's death was narrativized as a victory of good over evil, with the ritual centre created around values that could only be expressed in contrast to her and her achievements. In both cases - rituals of mourning and celebration - Thatcher's death brought people together; however, the senses of togetherness, belonging and participation were constructed via conflicting and converse values associated with her life.

Values, rituals and the management of contextual diversity

The key question in this paper, first posed by Robbins, is that of ritual's potential of encountering one single value at a time, hence helping people to manage complex situations in a condition of value pluralism. A simple answer would be that in a modern, mediatized condition, as illustrated in the media-saturated ritualization of the death of Lady Margaret Thatcher, such a condition is unlikely to exist. Rather, rituals as heterogeneous social and cultural performances involve a multiplicity of values encountered by a large quantity of people with a range of different value commitments. Whilst Thatcher's death triggered intensive ritualization in and via the media in Britain and elsewhere in the world, it seems difficult, even impossible, to identify one single value realised in that process.

However, even if we may disagree with Robbins' first condition when thinking about the relationship between ritual and values in a given setting, we may agree with the second condition - that is, the dynamics between monist and pluralist solutions at work. When looking from the monist perspective, a key to ritualizing Thatcher's death in a media setting was attention as 
a supervalue behind the logic of the media event, hence enforcing the media's own significance as the centre of social and cultural values played out in a mediatized British society. However, when considering how individual people used the media for ritual purposes, a multiplicity of values was evident. We might even say that the more intensive the ritualization and coherence felt inside of these mediatized 'ritual communities', the more divided the nation. In many cases, explicit conflicts between different values associated with her life and achievements seemed to occur, meaning people had to made tragic choices regarding which values to follow and different strategies for balancing the conflicted situation emerged. Some people managed the conflict between the different values by ignoring the media event and embedded conflicted values, while others participated in a negotiating process related to the different values. One example of this negotiation was an ongoing debate on Twitter over whether or not the tweets celebrating Thatcher's death were considered appropriate. In this case, the uncertainty of values also seemed to be at stake. Interestingly, many believed there was a lack of social space for neutral or dispassionate views, as people felt they were expected to take sides and express their values in public. Overall, we may agree that Thatcher's death activated simultaneous tendencies of pushing and pulling between monist and pluralist tendencies (as claimed by Robbins) in the media and its ritual performance of the death.

Finally, the journey from anthropology of religion to anthropology of media inspired by Robbins' insightful and thought-provoking work raises questions. Perhaps it is not so much shared beliefs in values that hold us together in today's largely pluralist condition, whether in Papua New Guinea or Britain, but rather the enactment of certain practices or, if you will, the performative power of rituals.

\section{References}

Anderson, Benedict. Imagined Communities. Reflections on the Origin and Spread of Nationalism. (rev. ed.) London: Verso, 1991.

Ginsburg, Faye; Abu-Lughod, Lila; Larkin, Brian. Media Worlds. Anthropology on New Terrain. Berkeley: University of California Press, 2002.

Castells, Manuel. Communication Power. Oxford: Oxford University Press, 2009.

Couldry, Nick. Media, Society, World. Social Theory and Digital Media Practice. Cambridge: Polity, 2012. 


\section{VALUES, RITUAL AND THE MANAGEMENT OF INTERCULTURAL DIVERSITY:}

TESTING THE GROUND IN THE MEDIA

Couldry, Nick. Media Rituals. A Critical Approach. London: Routledge, 2003.

Grimes, Ronald. Rite out of Place. Ritual, Media and the Arts. Oxford \& New York: Oxford University Press, 2006.

Meyer, Birgit. Material Mediations and Religious Practices of World Making. In Religion across Media. From Early Antiquity to Late Modernity. Knut Lundby (ed.) New York: Peter Lang, 1-19, 2013.

Murphy, Patrick; Kraidy, Marwan (eds.). Global Media Studies. Ethngraphic Perspectives. New York \& London: Routledge, 2003.

Silverstone, Roger. Media and Morality. On the Rise of the Mediapolis. Cambridge: Polity, 2007.

Sumiala, Johanna,. Media and Ritual. Death, Community and Everyday Life. London: Routledge, 2012.

Sumiala, Johanna; Tikka, Minttu. Imagining globalized fears: School shooting videos and circulation of violence on YouTube. Social Anthropology, n.3, 254-267, 2011. 
Johanna Sumiala

Debates do NER, Porto Alegre, ANO 15, N. 26, JUL/DEZ.2014. 